\title{
A Review on Outcome of Climate Change on Plant Diseases and their Management
}

\author{
Raina Bajpai* and Vandana Sahu \\ Department of Mycology and Plant Pathology, Banaras Hindu University, Varanasi, \\ Uttar Pradesh-221005, India \\ *Corresponding author
}

\section{A B S T R A C T}

\begin{tabular}{|l|}
\hline K e y w o r d s \\
$\begin{array}{l}\text { Climate change, Methane, } \\
\text { Plant disease, Ozone }\end{array}$ \\
\hline Article Info \\
\hline $\begin{array}{l}\text { Accepted: } \\
\text { 04 September } 2018 \\
\text { Available Online: } \\
\text { 10 October 2018 }\end{array}$ \\
\hline
\end{tabular}

Keywords

Climate change, Methane, Plant disease, Ozone

\section{Introduction}

In this era of modernization the most critical environmental challenge in whole world is climate change. In the atmosphere to warm the earth surface greenhouse gases like Methane $\left(\mathrm{CH}_{4}\right)$, nitrous oxide $\left(\mathrm{N}_{2} \mathrm{O}\right)$, carbon dioxide $\left(\mathrm{CO}_{2}\right)$, Ozone $\left(\mathrm{O}_{3}\right)$ and hydro fluoro carbons (HFCs) traps reflected radiation (Mahato, 2014). The major reason in raising worldwide climate changes that straightly affect the ecology is anthropogenic activities (Pachauri and Reisinger, 2007 and Ahanger et al., 2013). There are several factors behind alteration of climate (Pachauri and Reisinger, 2007 and Pachauri et al., 2014) and three component of disease triangle that is host; pathogen and environment are influenced by these changes
(Legreve and Duveiller, 2010). Throughout the world climate change is influencing plants in natural and agricultural ecosystems (Stern, 2007). Crops and their interaction with microbes are directly affected by climate change (Rosenzweig et al., 2000). Severe plant disease epidemics could be caused by this changing weather conditions (Bosch et al., 2007, Chakraborty, 2005) ultimately influencing the staple crop by risking food security (Anderson et al., 2004) and by injuring amenity species could harm landscapes (Bergot et al., 2004). Climate change also lead to variation in nature, occasion and occurrence of different diseases in horticultural crops. Enhancement in temperature, rising concentration of atmospheric $\mathrm{CO}_{2}$, change in pattern of 
precipitation and incidence of severe weather affects crop growth and production (Ghini et al., 2008; Chakraborty, 2011; Rosenzweig and Tubiello, 2007). Small life cycle pathogen reproduces in very high rates in the host and method of dispersal occurs speedily and quickly acclimatizes to changing climate (Coakley et al., 1999). Plant disease interactions are affected by $\mathrm{CO}_{2}$ concentration and increased temperature (Lopez et al., 2012) and thus threat perception of Phytophthora infestans causing late blight of potato, sheath blight caused by Rhizoctonia solani and blast caused by Magnaporthe grisea is enhanced (Kobayashi et al., 2006). Disease management strategies for sustainable food production should be according to change in climate. The level of carbon dioxide $\left(\mathrm{CO}_{2}\right)$ atmospheric concentration has risen considerably in comparison to previous six fifty thousand years (Siegenthaler et al., 2005). Same pattern is examined in different greenhouse gases like nitrous oxide $\left(\mathrm{N}_{2} \mathrm{O}\right)$ and methane $\left(\mathrm{CH}_{4}\right)$ etc. (IPCC, 2007, Spahni et al., 2005). Resulting, varied alteration in the climate has been accounted. In the past 30 years $0.2^{\circ} \mathrm{C}$ per decade increment in the average global surface has been noticed (Hansen et al., 2006). Changes in the water cycle have also been observed. The study of effect of nutrition, air humidity and wind on plant disease incidence was started at some stage in eighteenth century and the starting of the nineteenth century (Colhoun, 1973). The growth and multiplication of host and pathogen, spread of pathogen, their susceptibility, continued existence, activity along with interaction with host is influenced by environment. Morphological and physiological modification occurs due to disease which is itself a vibrant process in which is both host and pathogen environment (Gaumann, 1950). This secure relationship between the environment and diseases proposes that this change in climate may cause manipulation in the current phytosanitory picture. A proper study of climate change probable outcomes on plant diseases is necessary to take different adaptation methods, for the expansion of resistant cultivars and novel management techinques to stay away from more serious losses (Chakraborty and Pangga, 2004; Ghini, 2005). The nature of plant pathogens is ubiquitous in natural and the controlled schemes, thus its first to show the influence of climate change because of huge populations, reproduction easiness and dispersal, and narrow time among generations. Therefore, they form a basic assembly of biological displayer that needs to be studied for climate change impacts. The aim behind this review is to make understand and analyze the result of change in climate on the temporal and spatial allocation of plant diseases.

\section{Climate change and plant pathosystem}

A significant position is stood by plant diseases in agriculture (Agrios, 2005). The knowledge regarding the climate change on plant disease is still limited. The interactions between plant hosts, pathogens and environment could be elucidated by the effect of environment on the standard disease triangle which ultimately causes disease (Grulke, 2011). Disease-suppression to disease-conduction or vice versa could be caused by the long term environment variation coming under one of the incidents climate change (Fuhrer, 2003; Perkins et al., 2011). This demonstrates that plant diseases may act as indicator of climate change (Garrett et al., 2009). Under changing environmental conditions plant disease development longstanding datasets are uncommon (Scherm, 2004) however, if present it could display the key significance of environmental change for health of plant (Fabre et al., 2011). Generally under changed climate the health of plant is expected to suffer via different mechanisms like enhanced evolution of pathogen and reduced incubation periods because of 
augmented abiotic stress as there exists no matching among ecosystems and their climate and the additional recurrent incidence of severe weather occasions (Sutherst et al., 2011). For example, frequency of tree pathogens is supposed to be increased by drought mostly by not direct effects on host physiology (Desprez- Loustau et al., 2006). Direct effects of dry conditions have also noticed on pathogens like invasive exotic species another instance is of Heterobasidion irregulare in central Italy, well adjusted for distribution in the Mediterranean climate as compare to the native $H$. annosum species (Garbelotto et al., 2010). More ever, in insectvectored diseases, warmer temperatures causes increase in number of generation of insect, which ultimately increases invasive pathogen transmission rates (Robinet et al., 2011). Climate warming has been reported to be coupled with alteration in plant hosts for certain fungi (Gange et al., 2011). Few regional penalties on plant health due to climate change have been already observed like Phytophthora infestans in Finland (Hannukkala et al., 2007). It is anticipated that pathogens such as Sclerotinia sclerotiorum, Verticillium longisporum and Alternaria brassicae, and is supported by average warmer temperatures, particularly in long term. This was reported at Northern Germany, in oil rape (Siebold and von Tiedemann 2012).

Different elements of climate like moisture, carbon di oxide, temperature etc. has different effects on the plant disease. Let's discuss these effects in detail

\section{Moisture influence and its plant disease}

Due to rise in temperature, different models foretell events of frequent and extreme rainfall and higher atmospheric water vapor concentrations. This condition lead to good vegetative growth, canopy retaining high moisture and relative humidity thus creating a situation that is highly favorable also for causal organism and diseases like vegetable root diseases consisting powdery mildews and late blights (Coakley et al., 1999). Presence of high moisture favors foliar diseases and few soil borne pathogens like Pythium, R. solani, Phytophthora, and Sclerotium rolfsii. Viral disease incidence and severity was influenced by drought stress Beet yellows virus (BYV) and Maize dwarf mosaic virus (MDMV) (Clover et al., 1999, Olsen et al., 1990,).

\section{Effect of carbon dioxide on plant diseases}

Rise in the $\mathrm{CO}_{2}$ levels influences both the host and the pathogen in different ways. There are different symptoms depicting enhanced $\mathrm{CO} 2$ levels like increment in size of plant organs, leaf area, thickness of leaf, and leaves number, elevated total leaf area per plant, branches and stems with diameter increased (Pritchard et al., 1999, Bowes, 1993). The incidence of powdery mildew, rust, Stemphylium blight, anthracnose diseases and Alternaria blight are favored by dense canopy. It has been also reported that fungal spore production is enhanced by higher $\mathrm{CO}_{2}$ concentrations. Another report also states that due to rapidly increasing temperature and $\mathrm{CO}_{2}$, origin of new races may also take place. This occur as evolutionary forces creates pressure on large population of pathogen improved by a blend of augmented fecundity and infection cycles beneath advantageous microclimate in bloated canopy (Chakraborty, 2013). Few counteract action could be observed of $\mathrm{CO}_{2}$ effects on disease. Denser canopies due to high $\mathrm{CO}_{2}$ concentrations and high humidity enhances growth rates of leaves and stems this condition ultimately favor pathogens. Higher $\mathrm{CO}_{2}$ condition also lead to reduced decomposition of plants rates that increases the crop residue on which disease organisms can overwinter. Residue of crop causes enhanced inoculums level at the initial of the growing season eventually causing early and faster disease 
epidemic. This explains elevated $\mathrm{CO}_{2}$ concentration could lead to positive or negative effects on plant diseases, but in maximum of the cases disease severity has been increased (Manning and Tiedmann, 1995).

\section{Effect of rising temperatures on plant diseases}

Alteration in the temperature may evolve development of diverse inactive pathogens, which would lead an epidemic. Temperature and precipitation change leads to change in which eventually may am eventually alters the stages of growth, rate of development, causal organism's pathogenicity and host plants physiology and resistance (Charkraborty and Datta, 2003). In incidence diseases caused by bacteria like Acidovorax avenae, Burkholderia glumea and Ralstonia solanacearum temperature play a significant role. So, bacteria could easily flourish in the places where incidence of diseases relying on temperature has not been observed earlier (Kudela, 2009).

Studies has explained that with rise in temperature susceptibility of wheat and oats towards rust disease get enhanced, excluding few forage species gaining resistant with rise in temperature against fungi (Coakley et al., 1999). Increased temperature also induces reduction in the durability of resistance genes due to the evolution of pathogen races (Garrette, 2006). Variation in temperature influences the host resistance, by affecting heat induced susceptibility and temperature sensitive gene

\section{Effect of climate change in microbial interactions}

Carbon cycling and the functioning of various ecosystems are influenced due to augmented $\mathrm{CO}_{2}$ concentration in the atmosphere. The major factors influencing communities of soil microbes are deposition level of Nitrogen, temperature and concentration of $\mathrm{CO}_{2}(\mathrm{Garret}$ et al., 2006).

These short and extended-term alterations in the abiotic conditions influence growth of plant, their productivity and microbe's population surviving on. Plant growth and their ability to resist pathogens potential to attack the plants is influenced by modification in phyllosphere microflora (Fig. 1).

\section{Effect of climate change on vector-borne diseases}

The dispersal of plant viruses depends on the vectors and host. At local and regional level the threat of diseases of vector-borne and insect vector populations is dependent on the climatic requirements of disease vectors (Jones, 2009, Malmstrom et al., 2011). Global warming as well affects the host primary infection, the dispersal of infection in the host and or the diffusion of the virus horizontally to a fresh host via specific vector. Climate change also has impact on plant phenology and physiology, which manipulates susceptibility against virus. Moreover effects on host physiology may influence the pleasant appearance of the host towards vectors and transmissible ability of virus. Due to climate change there are different effect on vector like manipulations on vector phenology, vector's over-wintering, density, migration and their stability.

Elevated $\mathrm{CO}_{2}$ level have an effect on natural enemies of insect herbivores and through altering the dimension and composition of populationp of insects prey could indirectly influence the third trophic level. Thus, because of climate change any amend in plant population and population of insect vector could lead to dispersal of plant viruses (Canto et al., 2008). 
Fig.1 Climate change and its impacts. Here, $\mathrm{H}$ represents host, $\mathrm{P}$ stands for pathogen,

\section{E stands environment}

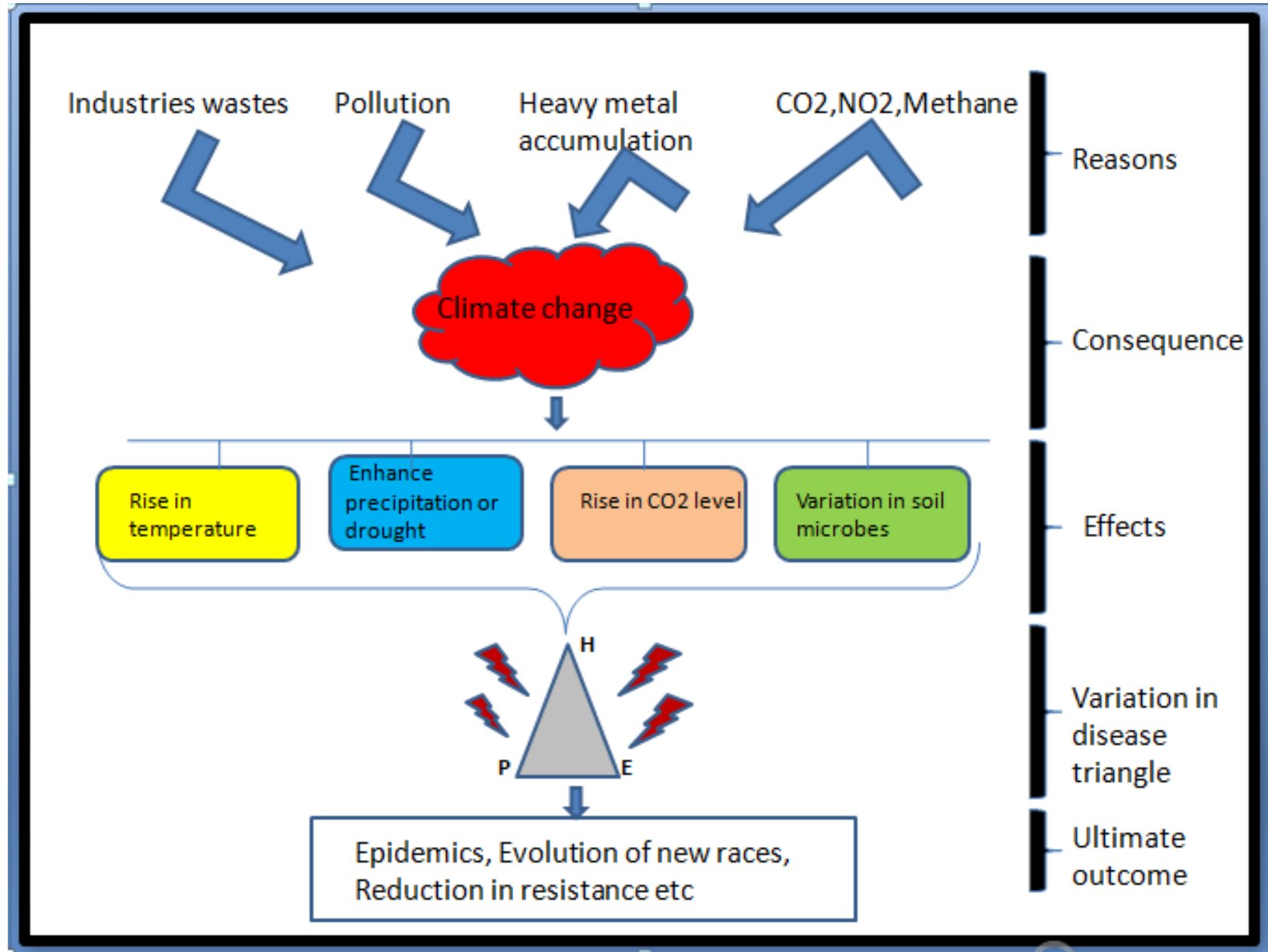

\section{Effect on fungicides}

By altering stages of pathogen and their development rate, change in climate amend the physiology of host-pathogen interactions thus alter host resistance and also lead to shift in the host and pathogen geographical distribution (Coakley et al., 1999). Under climate change situation few physiological transformation take place in host plants which may end result in increased resistance towards disease but this resistance via rapid disease cycles of pathogen could be easily break. The efficacy of fungicide and bactericide could be changed with increased $\mathrm{CO}_{2}$, moisture, and temperature. Forecast made by climate change models, the incidents of recurrent rainfall result in washing of chemicals creating difficulty for farmers to sustain the residues of contact fungicides over the plants, causing increased recurrent applications. Physiological changes negatively affect systemic fungicides by slow uptake rates due to reduced stomatal opening, thicking of epicuticular waxes in crop plants grown under higher temperatures. Degradation of pesticides is also influenced due to enhanced temperature, thus altering plants physiology and morphology influencing their infiltration, translocation and mode of action (Elad and Pertot, 2014). According to Ghini (2008) enhanced canopy due to elevated $\mathrm{CO}_{2}$ may influence the systemic fungicides infiltration, translocation and mode of action. Leaf surface 
characteristics also influences these chemicals like on retention of mancozeb on apple seedlings bean seedlings and knol-khol plants (Hunsche, 2006). He also reported strong negative correlation between fungicide retention and surface roughness and total cuticle wax. Thus he concluded that increased canopy size may have a negative impact on spray coverage and leading to dilution of active ingredients. As far as biological control is concerned less information is available.

\section{Handling the consequences of climate change on plant diseases}

These severe climatic conditions have created a huge pressure on growers as crops requirement for fungicide has increased. Fungicides higher spray treatments with higher application rates which eventually raise farmers cost of cultivation, charges for consumers and also develop resistance against fungicide (Juroszek and von Tiedemann, 2011). Including new cultivars and cultural practices for annual crops is quiet in comparison over perennials. To deal with this predicted climate change, first we should assess the worth of present chemical, biological and physical management methods and also acclimatizing novel tool and method (Coakley et al., 1999). Millar et al., (2007) reported that a single solution won't be sufficient to overcome this future climate change challenges but combination of different approaches adapted to different situations. Another outcome of climate warming is the invasive plant diseases spread in regions of naive host populations and this raises the need for greater than before monitoring and modelling (Loustau et al., 2007; Moricca and Ragazzi, 2009). Without the help of the complete variety of recent and fresh executive approach only diversification may not be ample instances on the basis of climate change models, suggestion have been made that it would develop into essential to augment the treatments figure of fungicide against Plasmopara viticola in Northern Italy wine-manufacturing area of over the next decades (Francesca et al., 2006). Moreover, increments of extension activities limiting the mistreatment and misuse of pesticides may also be well thought-out (Savary et al., 2011). In the nearby future the present dependence on economically attractive management tactics will be challenged not only due to climate change, also by advances in society. For an instance improved environmental issue awareness of, e.g. the new pesticide regulations come into force in the European Community (Mills et al., 2011; Erlacher and Wang, 2011). Employment of cultivar blending in fields and safeguarding of tree species thus maintaining diversity in forest are certain preventive measures which still make sense (Quijas et al., 2010; Wiman, 2007; Juroszek and von Tiedemann, 2011, Finckh and Wolfe 1996, Pautasso et al., 2005, Keesing et al., 2010, Bodin, 2007, Zhu et al., 2000, Garrett and Mundt, 1999). Further, innovative approaches would require, from assessment pest risks involving alteration in climate and economic considerations (Yemshanov et al., 2009). In present time importance of novel agro-ecosystems has increased in this context whereas innovative approaches in plant disease management should be used (Fitt, 2011; Newton et al., 2011).

Climate change operate at worlds wide due to short of epidemic processes reorganization at appropriate spatial and environmental scales the progress has been obstructed. In this area still limited research has been on climate change outcome on plant diseases beneath natural conditions on field or disease supervision in climate change. Changes in the rates of pathogen development, modification in resistance of host and alterations in the physiology of host - pathogen interaction eventually affecting plant diseases severity is 
only studied. Changing Climate may have constructive or destructive influence on pathosystem. The importance should be transferred to innovative adaptation and mitigation strategies from assessment of outcomes. Initially, assessment of the utility of present chemical, physical, and biological management strategies, involving diseaseresistant cultivars, under climate change. Another is to involve situations of future climate in whole research meant at rising novel tools and plans. The analysis of disease risk may be relied on interactions of hostpathogen and researches on responses of host. The experiments should be made to explore the real inter relation between changing climate and microbes and to find out the best solution to adapt the current scenario and much more to come.

\section{References}

Agrios, G. N. 2005. Plant Pathology. p. 249263. 5th edition. London: Elsevier

Ahanger, R. A., Bhat, H. A., Bhat, T. A., Ganie, S. A., Lone, A. A., Wani, I. A., Ganai, S. A., Haq, S., Khan, O. A., Junaid, J. M. and Bhat, T. A. (2013). Impact of Climate Change on Plant Diseases. International Journal of Modern Plant \& Animal Sciences, 1(3), 105-115

Anderson, P. K., Cunningham, A. A., Patel, N. G., Morales, F. J., Epstein, P. R., and Daszak, P. (2004). Emerging infectious diseases of plants: pathogen pollution, climate change and agrotechnology drivers. Trends in Ecology \& Evolution, 19(10), 535-544.

Bergot, M., Cloppet, E., Pérarnaud, V., Déqué, M., Marçais, B., and Desprez- Loustau, M. L. (2004). Simulation of potential range expansion of oak disease caused by Phytophthora cinnamomi under climate change.
Global Change Biology, 10(9), 15391552.

Bodin, P., and Wiman, B. L. (2007). The usefulness of stability concepts in forest management when coping with increasing climate uncertainties. Forest Ecology and Management, 242(2-3), 541-552.

Bosch, J., Carrascal, L. M., Duran, L., Walker, S., and Fisher, M. C. (2007). Climate change and outbreaks of amphibian chytridiomycosis in a montane area of Central Spain; is there a link? Proceedings of the Royal Society of London B: Biological Sciences, 274(1607), 253-260.

Bowes, G. (1993). Facing the inevitable: plants and increasing atmospheric $\mathrm{CO} 2$. Annual review of plant biology, 44(1), 309-332.

Canto, T., Aranda, M. A., and Fereres, A. (2009). Climate change effects on physiology and population processes of hosts and vectors that influence the spread of hemipteran- borne plant viruses. Global Change Biology, 15(8), 1884-1894.

Chakraborty, S. (2005). Potential impact of climate change on plant-pathogen interactions. Australasian Plant Pathology, 34, 443-448

Chakraborty, S. (2013). Migrate or evolve: options for plant pathogens under climate change. Global change biology, 19(7), 1985-2000.

Chakraborty, S., and Datta, S. (2003). How will plant pathogens adapt to host plant resistance at elevated $\mathrm{CO}_{2}$ under a changing climate? New Phytologist, 159(3), 733-742.

Chakraborty, S., and Newton, A. C. (2011). Climate change, plant diseases and food security: an overview. Plant Pathology, 60(1), 2-14.

Chakraborty, S., and Pangga, I. B. (2004). Plant disease and climate change. In 
Plant microbiology. Taylor \& Francis.187-205

Clover, G. R. G., Smith, H. G., Azam-Ali, S. N., and Jaggard, K. W. (1999). The effects of drought on sugar beet growth in isolation and in combination with beet yellows virus infection. The Journal of Agricultural Science, 133(3), 251-261.

Coakley, S. M., Scherm, H., and Chakraborty, S. (1999). Climate change and plant disease management. Annual review of phytopathology, 37(1), 399-426.

Colhoun, J. (1973). Effects of environmental factors on plant disease. Annual Review of Phytopathology, 11(1), 343-364.

Desprez-Loustau, M. L., Marçais, B., Nageleisen, L. M., Piou, D., and Vannini, A. (2006). Interactive effects of drought and pathogens in forest trees. Annals of Forest Science, 63(6), 597612.

Desprez-Loustau, M. L., Marçais, B., Nageleisen, L. M., Piou, D., and Vannini, A. (2006). Interactive effects of drought and pathogens in forest trees. Annals of Forest Science, 63(6), 597612.

Elad, Y., and Pertot, I. (2014). Climate change impacts on plant pathogens and plant diseases. Journal of Crop Improvement, 28(1), 99-139.

Erlacher, E., and Wang, M. (2011). Regulation (EC) No. 1107/2009 and upcoming challenges for exposure assessment of plant protection products-Harmonisation or national modelling approaches? Environmental pollution, 159(12), 3357-3363.

Fabre, B., Piou, D., Desprez-Loustau, M. L., and Marcais, B. (2011). Can the emergence of pine Diplodia shoot blight in France be explained by changes in pathogen pressure linked to climate change? Global Change Biology, 17(10), 3218-3227.
Finckh, M. R., and Wolfe, M. S. (1997). The use of biodiversity to restrict plant diseases and some consequences for farmers and society. In Ecology in agriculture. 203-237.

Fitt, G. P. (2011). Critical issues in pest management for a future with sustainable biofuel cropping. Current Opinion in Environmental Sustainability, 3(1-2), 71-74.

Francesca, S., Simona, G., Francesco Nicola, T., Andrea, R., Vittorio, R., Federico, S., Rettori Andrea, Rossi Vittorio, Spanna Federico, Rosenzweig Cynthia, and Gullino and Maria Lodovica, G. (2006). Downy mildew (Plasmopara viticola) epidemics on grapevine under climate change. Global Change Biology, 12(7), 1299-1307.

Fuhrer, J. (2003). Agroecosystem responses to combinations of elevated $\mathrm{CO} 2$, ozone, and global climate change. Agriculture, Ecosystems \& Environment, 97(1-3), 1-20.

Gange, A. C., Gange, E. G., Mohammad, A. B., and Boddy, L. (2011). Host shifts in fungi caused by climate change? Fungal Ecology, 4(2), 184-190.

Garbelotto, M. (2008). Molecular analysis to study invasions by forest pathogens: examples from Mediterranean ecosystems. Phytopathologia Mediterranea, 47(3), 183-203.

Garrett, K. A., and Mundt, C. C. (1999). Epidemiology in mixed host populations. Phytopathology, 89(11), 984-990.

Garrett, K. A., Dendy, S. P., Frank, E. E., Rouse, M. N., and Travers, S. E. (2006). Climate change effects on plant disease: genomes to ecosystems. Annual review of phytopathology, 44, 489-509.

Garrett, K. A., Nita, M., De Wolf, E. D., Esker, P. D., Gomez-Montano, L., and Sparks, A. H. (2015). Plant pathogens as indicators of climate change. In 
Climate Change (Second Edition). 325338.

Gaumann, E. (1950). Principles of plant infection. Crosby Lockwood and Son, Ltd., London.

Ghini, R. (2005). Mudanças climáticas globais $e$ doenças de plantas. Jaguariúna: Embrapa Meio Ambiente. 104.

Ghini, R., Hamada, E., and Bettiol, W. (2008). Climate change and plant diseases. Scientia Agricola, 65(SPE), 98-107.

Grulke, N. E. (2011). The nexus of host and pathogen phenology: understanding the disease triangle with climate change. New Phytologist, 189(1), 8-11.

Hannukkala, A. O. (2011). Examples of alien pathogens in Finnish potato productiontheir introduction, establishment and consequences. Agricultural and Food Science, 20(1), 42-61.

Hansen, J., Sato, M., Ruedy, R., Lo, K., Lea, D. W., and Medina-Elizade, M. (2006). Global temperature change. Proceedings of the National Academy of Sciences, 103(39), 14288-14293.

Hunsche, M., Bringe, K., Schmitz- Eiberger, M., and Noga, G. (2006). Leaf surface characteristics of apple seedlings, bean seedlings and kohlrabi plants and their impact on the retention and rainfastness of mancozeb. Pest Management Science: formerly Pesticide Science, 62(9), 839-847.

IPCC. (2007). Climate change 2007: Synthesis Report. Contribution of Working Group I, II and III to the Fourth Assessment Report of the Intergovernmental Panel on Climate Change (IPCC). R. K. Pachauri and A. Reisinger (Eds.), IPCC, Geneva, Switzerland.

Juroszek, P., and Von Tiedemann, A. (2011). Potential strategies and future requirements for plant disease management under a changing climate. Plant Pathology, 60(1), 100-112.

Keesing, F., Belden, L. K., Daszak, P., Dobson, A., Harvell, C. D., Holt, R. D., Hudson, P., Jolles, A., Jones, K.E., Mitchell, C.E. and Myers, S. S. (2010). Impacts of biodiversity on the emergence and transmission of infectious diseases. Nature, 468(7324), 647.

Kobayashi, T., Ishiguro, K., Nakajima, T., Kim, H. Y., Okada, M., and Kobayashi, K. (2006). Effects of elevated atmospheric $\mathrm{CO} 2$ concentration on the infection of rice blast and sheath blight. Phytopathology, 96(4), 425-431.

Kudela, V. (2009). Potential impact of climate change on geographic distribution of plant pathogenic bacteria in Central Europe. Plant Protection Science, 45, 527-532.

Legrève, A., and Duveiller, E. (2010). Preventing potential diseases and pest epidemics under a changing climate. Climate change and crop production, 1 , 50-70.

Mahato, A. (2014). Climate change and its impact on agriculture. International Journal of Scientific and Research Publications, 4(4), 1-6.

Malmstrom, C. M., Melcher, U., and BosquePérez, N. A. (2011). The expanding field of plant virus ecology: historical foundations, knowledge gaps, and research directions. Virus Research, 159(2), 84-94.

Manning, W. J., and Tiedemann, A. V. (1995). Climate change: potential effects of increased atmospheric carbon dioxide $\left(\mathrm{CO}_{2}\right)$, ozone $\left(\mathrm{O}_{3}\right)$, and ultraviolet-B (UV-B) radiation on plant diseases. Environmental Pollution, 88(2), 219-245.

Millar, C. I., Stephenson, N. L., and Stephens, S. L. (2007). Climate change and forests of the future: managing in the face of 
uncertainty. Ecological applications, 17(8), 2145-2151.

Mills, P., Dehnen-Schmutz, K., Ilbery, B., Jeger, M., Jones, G., Little, R., MacLeod, A., Parker, S., Pautasso, M., Pietravalle, S.\& Maye, D. (2011). Integrating natural and social science perspectives on plant disease risk, management and policy formulation. Philosophical Transactions of the Royal Society of London B: Biological Sciences, 366(1573), 2035-2044.

Newton, A. C., Johnson, S. N., and Gregory, P. J. (2011). Implications of climate change for diseases, crop yields and food security. Euphytica, 179(1), 3-18.

Olson, A. J., Pataky, J. K., D'arcy, C. J., and Ford, R. E. (1990). Effects of drought stress and infection by maize dwarf mosaic virus on sweet corn. Plant disease, 74(2), 147-151.

Pachauri, R. K., Allen, M. R., Barros, V. R., Broome, J., Cramer, W., Christ, R., Church, J.A., Clarke, L., Dahe, Q., Dasgupta, P., Dubash, N. K., Edenhofer, O., Elgizouli, I.,Field, C. B., Forster, P., Friedlingstein, P., Fuglestvedt, J., Gomez-Echeverri, L.,Hallegatte, S., Hegerl, G., Howden, M., Jiang, K., Jimenez Cisneroz, B., Kattsov, V., Lee, H., Mach, K. J., Marotzke, J., Mastrandrea, M. D., Meyer, L., Minx, J., Mulugetta,Y., O’Brien, K., Oppenheimer, M., Pereira, J. J., Pichs Madruga, R., Plattner, G. K.,Portner, H. O., Power, S. B., Preston, B., Ravindranath, N. H., Reisinger, A., Riahi, K., Rusticucci, M., Scholes, R., Seyboth, K., Sokona, Y., Stavins, R., Stocker, T. F., Tschakert, P., Van Vuuren, D. \&Van Ypserle, J. P. (2014). Climate change 2014: Synthesis report. p. 151. In R. Pachauri and L. Meyer (Eds.) Contribution of working groups I, II and III to the fifth assessment report of the intergovernmental panel on climate change. Switzerland. Geneva.

Pautasso, M., Holdenrieder, O., and Stenlid, J. (2005). Susceptibility to fungal pathogens of forests differing in tree diversity. In Forest diversity and function (pp. 263-289). Springer, Berlin, Heidelberg.

Perkins, L. B., Leger, E. A., and Nowak, R. S. (2011). Invasion triangle: an organizational framework for species invasion. Ecology and evolution, 1(4), 610-625.

Quijas, S., Schmid, B., and Balvanera, P. (2010). Plant diversity enhances provision of ecosystem services: a new synthesis. Basic and Applied Ecology, 11(7), 582-593.

Robinet, C., Van Opstal, N., Baker, R., and Roques, A. (2011). Applying a spread model to identify the entry points from which the pine wood nematode, the vector of pine wilt disease, would spread most rapidly across Europe. Biological Invasions, 13(12), 29812995.

Rosenzweig, C., and Tubiello, F. N. (2007). Adaptation and mitigation strategies in agriculture: an analysis of potential synergies. Mitigation and Adaptation Strategies for Global Change, 12(5), 855-873.

Salvatore, M., and Alessandro, R. (2009). Lusus naturae: cambiamenti climatici ed invasioni di parassiti vegetali modificano il territorio agro-forestale. Ital. J. Agron, 3, 13-17.

Savary, S., Nelson, A., Sparks, A. H., Willocquet, L., Duveiller, E., Mahuku, G., Forbes, G., Garrett, K.A., Hodson, D., Padgham, J. and Pande, S. (2011). International agricultural research tackling the effects of global and climate changes on plant diseases in the developing world. Plant Disease, 95(10), 1204-1216. 
Scherm, H. (2004). Climate change: can we predict the impacts on plant pathology and pest management? Canadian Journal of Plant Pathology, 26(3), 267273.

Siebold, M., and Von Tiedemann, A. (2012). Potential effects of global warming on oilseed rape pathogens in Northern Germany. Fungal Ecology, 5(1), 62-72.

Siegenthaler, U., Stocker, T. F., Monnin, E., Lüthi, D., Schwander, J., Stauffer, B., Raynaud, D., Barnola, J.M., Fischer, H., Masson-Delmotte, V., and Jouzel, J. (2005). Stable carbon cycle-climate relationship during the late Pleistocene. Science, 310(5752), 1313-1317.

Spahni, R., Chappellaz, J., Stocker, T. F., Loulergue, L., Hausammann, G., Kawamura, K., Fluckiger, J., Schwander, J., Raynaud, D., MassonDelmotte, V. and Jouzel, J. (2005). Atmospheric methane and nitrous oxide of the late Pleistocene from Antarctic ice cores. Science, 310(5752), 13171321.

Stern, N. (2007). The Economics of Climate Change: The Stern Review. Cambridge University Press, Cambridge, UK.
Sutherst, R. W., Constable, F., Finlay, K. J., Harrington, R., Luck, J., and Zalucki, M. P. (2011). Adapting to crop pest and pathogen risks under a changing climate. Wiley Interdisciplinary Reviews: Climate Change, 2(2), 220237.

Yáñez-López, R., Torres-Pacheco, I., Guevara-González, R. G., HernándezZul, M. I., Quijano-Carranza, J. A., and Rico-García, E. (2012). The effect of climate change on plant diseases. African Journal of Biotechnology, 11(10), 2417-2428.

Yemshanov, D., McKenney, D. W., Pedlar, J. H., Koch, F. H., and Cook, D. (2009). Towards an integrated approach to modelling the risks and impacts of invasive forest species. Environmental Reviews, 17(NA), 163-178.

Zhu, Y., Chen, H., Fan, J., Wang, Y., Li, Y., Chen, J., Fan, J., Yang, S., Hu, L., Leung, H. and Mew, T. W. (2000). Genetic diversity and disease control in rice. Nature, 406(6797), 718.

\section{How to cite this article:}

Raina Bajpai and Vandana Sahu. 2018. A Review on Outcome of Climate Change on Plant Diseases and their Management. Int.J.Curr.Microbiol.App.Sci. 7(10): 120-130. doi: https://doi.org/10.20546/ijcmas.2018.710.014 